International Journal of Engineering \& Technology, $7(3.21)(2018) 227-231$
International Journal of Engineering \& Technology
SPC
Website: $\frac{\text { www.sciencepubco.com/index.php/IJET }}{\text { Research paper }}$

\title{
Farmland, Farm Credit and Agricultural Output Growth in Kano State, Nigeria: the Moderating Role of Murabahah Finance as a Proposed Framework
}

\author{
Ahmad Bashir @ B.Aziz ${ }^{1}$,Ahmed Ibrahim Mohammed ${ }^{2}$ \\ ${ }^{1,2}$ Islamic Business School, University Utara Malaysia, 06010 UUM Sintok. Kedah Darul Aman, Malaysia \\ *Corresponding author E-mail: ahmad.ibrahimmuhammad@yahoo.com
}

\begin{abstract}
The objective of this paper is to propose a model to examine the moderating role of Murabahah finance on farmland, farm credit and agricultural output. Since, agriculture is the science and act of soil utilization, animals and forestry management in respect of food and raw materials for human satisfaction as well as poverty control and economic growth. On the other hand, the Kano state agricultural output is declining all with the socio-economic role of the output in the state economy. This paper proposes a model consider to be used by the ministry of agriculture and financial institutions in Kano state, Nigeria in order to overcome such issues. In addition, this paper introduces Murabahah finance as a new variable into the model and potential moderating variable. Also, this paper used a conceptual methodological approach.
\end{abstract}

Keywords: Agricultural Output; Farmland; Farm Credit; Conceptual framework

\section{Introduction}

Agriculture serves as machinery for global food supply and employment opportunities for poverty eradications $(1,2)$. Equally, agriculture remains a key driver for sustainable life through the food supply, income generation and raw materials to the industries as well as economic growth and development $(3,4)$. The agricultural growth and development are relied on satisfactory farm input such as; farmland, farm credit and other farm infrastructure (labour force, education and training, Tractors, Planters, water pumping machines among others) (5).

Likewise, the growth of the agricultural output serve as a machinery of achieving the Sustainable Development Goals (MDGs) by the developing economies as such output remained a major source of income to the majority of African countries as well as other developing economies (6). Equally, the African economy is solidly dependent on agricultural production. In addition, agricultural productions increase the speed of sustainable living and economic growth of the African nations more specifically, in Nigeria as the largest population in the African countries with the advantage of fertile soil which support agricultural production. Nigeria was among the highest African exporters of agricultural output with the following output cotton, hide and skin, cocoa, palm-oil, groundnut and rubber among others $(2,7)$. Furthermore, Kano of Nigeria is blessed with fertile soil and higher population which is over 15 million in 2016 (National Population Commission (NPC) 2014). The state is commercially inclined with agricultural output and agribusiness (8).

In describing the importance of agriculture, the former governor of Kano state, emphasized that economic growth of the state is vested on agricultural output that is why the government gave high priority to the agricultural activities and agribusiness. This shows that government is concerned with the sector, the total sum of 8.802 billion Naira, and representing 6.42 percent of the state government budget, was injected into the agricultural output project schemes and programs for the year 2012(9). In additions, Kano state government collaborated with the federal government, and worthy partners in an agricultural output scheme, project and commercial agriculture development plan among others includes the National Food Security Plan, the 3rd National Fadama Development and Seventies Foundation Program. The expenditure on the project was 4.365 billion Naira in the financial year of 2013. Also, 800 million Naira was used for the purchase of industrial raw materials to the Kano Agricultural Supply Company (KASCO) (9).

Despite the above mention role played by the state government and other private bodies to the sector and yet, the agricultural output is declining in the state. This is due to the inadequate agricultural financing to settle the issues in relation to the farmland and farm credit which resulted to the problems such as: insufficient fertilizer, poor storage facilities and poor transportation among others $(5,8)$. Similarly, such problems have accelerated the state food insecurity, unemployment and poverty. However, researches on the area revealed mixed results which are in line with the study of Baron \& Kenny (10) that the existence of inconsistent results needs the inclusion of a moderator. With this reason, this study is incorporating Murabahah finance to serve as a moderator on the relationship between farmland, farm credit and agricultural output in order to improve the relationship between the variables. Since, Murabahah finance is a Shariah mode of transaction that assists needy farmers, traders and farmer's cooperatives or association. This Islamic financial product is free from interest rate, manipulation and exploitation as it is an agreed trade over a given product. 


\section{Literature Review on Agricultural Output}

Agriculture refers to a discipline which concerned about the cultivation of soil in order to support plant and animals for the purpose of man's economic satisfaction and other channels of nation's economic growth and development (11). It is a channel of crop growth and animal husbandry for the primary satisfaction of human and industrial system $(12,13)$. Similarly, it looks at the land preparation for the growth of food to the man and supply of raw material to the industries (4). In addition, farm produce, farm output and agricultural output or commodities are regarded as the outcome of the available farm input as a factor of such production, which is yielding a food security, poverty reduction and employment generation among others (2). Agriculture is a study that deals with the soil utilizations for food to the man and feed to the animals and reservation of forest for human satisfaction and economic growth (12). Additionally, International Finance Co-operation (IFC) define agriculture based on four (4) categories such as:

i. Subsistence agriculture is a system which is practices by the small scale farmers mainly for their household consumption and sold the surplus to settle the household demands. Farmers from these categories are in use of traditional tools, seeds as well as lacking credit facilities to boost their agricultural activities.

ii. Diversified agricultural business is a commercial farming system which is divides the farm into segment of foodstuffs for family consumptions and the segment of commercial production.

iii. Commercial agriculture refers to farm enterprises which are concentrated on producing only one type of crop or type of livestock, mainly for market purposes. This type of farming is basically a large scale production and modest in size. Also, agricultural output of commercial agriculture is purchased by the intermediaries while the intermediaries will sell to the middlemen and exporters.

iv. Food enterprises: This category of agricultural system is practices to produce primary output or food stuff mainly for trade and earning income for a sustainable living of rural dwellers.

Furthermore, agriculture can also be regarded as a production strategies of transformation of combined factors to create a marketable farm output $(5,14)$. It is also remains a sustainable mode of living in terms of food supply, income, employment, market and industries. It is a central driver for poverty eradication and economic growth through supply of farm produce and market (11) Agricultural output can equally be seen as an as outcome of land cultivation of land and animals rearing as well as processing and marketing $(3,13)$. Also, it is a yield of farming, processing marketing and consumption as well as economic growth and development (5).

\subsection{Farmland}

Land is the top space of the earth, which is richer in terms of plant nutrients and space for animal rearing as well as needed agriculture- related raw materials for human satisfaction and economic growth (15). Similarly, Maletta (16) described it as a major factor of production, mostly in the agricultural sector. Likewise, referring to such land used in crop growing and rearing of animals for man and industrial uses, as well as economic growth and development. It is also comprised of fertile soil, space for supporting animal, poultry and forest management for sustainable living and socioeconomic advancements. As such farmland serves as a pillar of all agricultural productivity (17).

\subsection{Farmland and Agricultural output}

Jayne, Chamberlin and Headey (18) found the relationship between farmland and agricultural output in Kenya and the study examined the decrease of the arable land from $68 \%$ to $24-22 \%$ due to the densely population. Likewise, the study of Mattthew \& Uchechukwu (19) found a negative relationship between farmland and farm produce in Nigeria. In addition, Okuthe, Ngesa \& Ochola (20) reported a negative impact between farmland and output of sorghum in Kenya. Similarly, the study of Simtowe, Zeller \& Diagne (21) indicated a positive relationship between farmland and agricultural output in Malawi. Similarly, Maletta (16) had shown a significant associated of farmland on agricultural output. Likewise, Kan, Haim, Rapoport-Rom \& Shechter (17) indicated a positive relationship between farmland and farm output in Israel. Thus, the study established the following Hypothesis. Hypothesis 1: farmland influences the agricultural output.

Garrett, Lambin \& Naylor (22) reported the negative relationship between farmland tenure and suybean production yield (output) in Brazil. Data captured from the county level. On the other hand, Simtowe, Zeller \& Diagne (21) reported a positive relationship between farmland and agricultural output in rural areas of Malawi. The Data were analysed by the treatment effect model. Similarly, Maletta (16) revealed that farmland is related to agricultural out. Also, he explains that agricultural development refers to land utilized for agriculture output. As global population has been increasing faster, which is already reaching almost seven billion, and is expected to reach nine billion by 2050 , so, the more farmland will be demanded to meet up the need of the growing population, and this will be tempered with available farmland.

Bastian et al. (23) established survey that reported positive relationship between farmland values and agricultural output. The Data were analysed through Geographic Information System (GIS) on examining the recreational and scenic aminities associated with farmland. Also model of hedronic price is specified by GIS examination. It's considered to estimate the importance of amienity and agricultural output, land features or price per acre for a wyorning sample of agricultural parcels. And the findings indicated that the specification farmed across various functional forms Also the land prices sampled are explained by degree of environmental amenities and the attitude of agricultural production. Equally, amenity variables which included views of scenic are statistically significant.

Kan et al. (17) reported the positive relationship between farmland and agricultural output in relation to environmental facilities and optimal land used for agricultural production in Israel. Positive mathematical programming model was used to capture data in the northern region of Israel, considering crop-discriminating ameniety- benefits function. Changes in allocating farmland increase farmer's welfare by 2.4 percent nationwide, also by up to 15 percent or the regional stage. Regional farming scale on profit and loss level was amounted to 6 percent. Due to the nature of decreasing return-to-scale of ameinity benefits function and the cross- regional variability sensitively appears in the way and manner in which the country is regionally divided.

It is established an empirical study which shows that farmland is positive and significant to agricultural output in Iran. Data was gathered through distributed two hundred and fifty questionnaires and cronbach's alpha ware used for the analysis. They further indicated that there is a significant difference between the variables in terms of membership and vice versa. Equally, Allahyari, Poshtiban \& Koundinya (15) reported a positive relationship between farmland and agricultural output in Guida area of Iran. Also, Questionnaires were used in data collection. Equally, the finding indicated that economics factors impacted more on agricultural land changes in Guilan and followed by management, social and relevant policy making, personal and technical also impacted more on land use changes. In addition, growth of population and expansion of the physical face of the cities was the most influential social factor in changing the farmland. 


\subsection{Farm Credit}

Agricultural funding popularly known as a farm credit and referred as an instrument use to boost the combine factors of farm production and poverty reduction as well as production of farm goods and services $(5,24)$. It is also valuable material either in cash or in kind used to employ farming satisfaction through formal or informal financial institutions (Awe, 2013). Equally, it is equally, be described as a financial transaction set to enhance farming activities with due respect to the received and repayment conditions over a period of time (25) .

Consequently, farm Credit serves as a certain amount of money under the custody of financial institutions ready to lend out to the needy farmers as per repayment condition at a specific future period of time (Anthony, 2010). Furthermore, it can be a systematic procedure of power acquisition of control of money for the purpose of agricultural activities within a design period and conditions (21)

\subsection{Farm Credit and Agricultural Output}

Eyo (26) established relationship between farmer's credit and agricultural output in Nigeria. Also, Chasisa (27) related farm credit and agricultural output in South Africa with positive result. Ammani found positive results in Nigeria where he established relationship between farm credit and output. Chisasa (4) shows a positive and significant relationship in South Africa. Mattthew \& Uchechukhu (19) reported a negative result on the relationship between credit to the farmers and agricultural output in Nsuka, Nigeria. In addition, Onyenchenya \& Ukala (24) indicated a mixed result in Nigeria.

Atagana and Kalu analysed that farm credit is negatively impacted in agricultural output. The Data were analysed by using a linear model based on production function of theory of production over the finding of the impact of the ACGSF In providing credit in agricultural development. In addition, Awe (28) analysed that farm credit is positively influenced agricultural production output. Data were captured and analyzed through vector repressiveness model (VAR) also time series data from 1980 to 2009 were considered. Moreover, Oyeyinka \& Bolarinwa (29) reported mixed result between farm credit agricultural output in rural areas of Oyo State South-western Nigeria. Data was gathered through systematic simple random sampling method distributed a questionnaire to one hundred and thirty farmers.

Oguoma, Ben-chendo \& Henri- Ukoha (25) examined Agricultural credit Guarantee scheme fund and reported that farm credit is positively influenced agricultural output growth and development in Nigeria. Similarly, Furthermore, Nwosu et al. (25) studied that farm credit under ACGSF has a positive contribution regards to agricultural output in Nigeria. Equally, Anthony (5) reported negative relationship between farm credit and agricultural output in Nigeria. The data source for his study include publication from Central Bank of Nigeria (CBN) various issues, of annual report and statement of account and statistical bulletin; National bureau of statistics various issues and internet publication of policy issues on agriculture in Nigeria.

Matthew \& Uchechukhu (19) reported a mixed results between farm credit and agricultural output in rural areas of Nsuka local government of Enugu state, Nigeria. Data were generated from sixty small scale farmers by multistate and interview technique as well as descriptive statistics was employed in data analysis. In addition, Onyenchenya \& Ukala (24) revealed mixed results between farm credit and agricultural output and study were conducted on Nigeria Agriculture cooperatives and rural Development Bank (NACB). Data were gathered by using Random sample of ninety small scale farmers. Furthermore, Klinefelter \& Penson (30) revealed that farm credit is relevant to agricultural output in Philippines, due to middlemen and brokers engaged business on agricultural output mostly have some collateral that resulted in developed intimate relationship with traders on transactions regard to agricultural output.

Brambilla \& Porto (31) explained that farm credit is significant to agricultural output in Zambian cotton farms where farmers took farm credit from a giving institution while disposing the farm output to another institution which leads to the increase in interest rate and other administrative charges that resulted in less profit in cotton production and culminated to rise in farmer defaults. It is also examined that small scale farmer's of cash-crop in a liberalized market of cashew and cotton in Tanzania, Pakistan and Ghana. Their findings indicated that farm credit is significantly influenced agricultural output.

Furthermore, farm credit is proportionate to the increase in agricultural output, and this is defined as agricultural output increase by farm credit which is in line with the theory of production function. Thus, farm credit instituted by a farmer should theoretically able to increase agricultural output. More so, positive relationship between farm credit and agricultural output is consistent with the findings of Chisasa, (27) who stated that when farm credit is provided for farmers, there will be more agricultural output. Also, Ammani (13) result is similar to this study. He reported that farm credit serves as an accelerator of agricultural output. Thus, the study state the following developed Hypothesis.

Hypothesis 2: farm credit influences the agricultural output.

\subsection{Farmland, Farm Credit, Murabahah Finance and Agricultural Output}

Murabahah finance (cost-plus-profit or mark-up sale), can be defined as a Shariah financing system in which the commodity seller reveals the total cost of the commodity to the buyer where both buyer and seller agreed upon a given profit margin $(32,33)$. It is also, be regarded as a contract in which customer (farmer) wishing to buy goods or farm equipment on requesting his bank to purchase the products and resell the products with addition of agreed declared profit margin (34).

Furthermore, the study of Hilmy (35) indicated Murabahah finance was positive in land cultivation toward farm produce in Sri Linka. Equally, Mastoor (36) established a positive relationship between Murabahah finance farmland cultivation. Also, Mohammed \& Hussien (37) reported a positive relationship between $\mathrm{Mu}$ rabahah and irrigation agricultural production in Sudan. Also, Mastoor (36) reported that farm credit and other farm infrastructure should be provided to the republic of Sudan farmers Equally, Bank Negara Malaysia, Bursa Malaysia and Islamic financial industry and Securities Commission had collaboratively intiated an electronic Shariah web-based commodity trading platform named Commodity Murabahah House (CMH). This was started with the crude palm oil (CPO) product trading with ringgit as a transactive mode specifically at $\mathrm{CMH}$. Also, $\mathrm{CMH}$ recognised trading in other foreign currencies in order to wider options range, flexibility and access of the international financial institutions to join the Shariah trading market (http://www.bnm.gov.my).

Saddiqi (38) and Khaleequzzaman \& Shirazi (39) revealed that Islamic financial institutions utilised Murabahah product in financing trade and agricultural activities in terms of input (farm equepments) and output (crops) of production. it is now an empirically established fact that Murabahah financing tops the list of the available modes of Islamic finance in terms of popularity toward financing trading and agricultural production (40). Similarly, Obaidullah \& Mohamed-Saleem (41) established a positive relationship between Murabahah and agricultural financing in SriLanka. This issue concentrates on financing paddy agriculture for displaced and impoverished farmers. Notwithstanding, Aburaida (42) reported a positive relationship between Murabahah and farm credit in a study entitled rural finance as a tool for poverty reduction in Sudan. Also, the study further explained that, Murabahah financing was among the successful products after the Islamization of Sudan banking industry. However, the study established 
the following Hypothesis 3: Murabahah finance influence farmland and farm credit on agricultural output.

\section{Methodology}

This paper proposes the consideration of the Partial Least Square Structural Equation Modeling (PLS-SEM) on Smart PLS software for data analysis. This is related to the study of Hair, Black, Babin and Anderson (43) that PLS is a recognized method of data analysis because, it is more advantageous than any other software in the examination of cause-effect analysis related to the latent variables relationship. Equally, PLS-SEM modeling method of analysis is superior in terms of prediction and examination of the relationship between variables (44).

\subsection{Proposed Research Frame Work}

The following proposed framework is based on the evidences found in the above empirical studies to illustrate the relationship between farmland, farm credit and agricultural output with the moderating role of Murabahah finance as depicted in Figure 1 below.

IVs

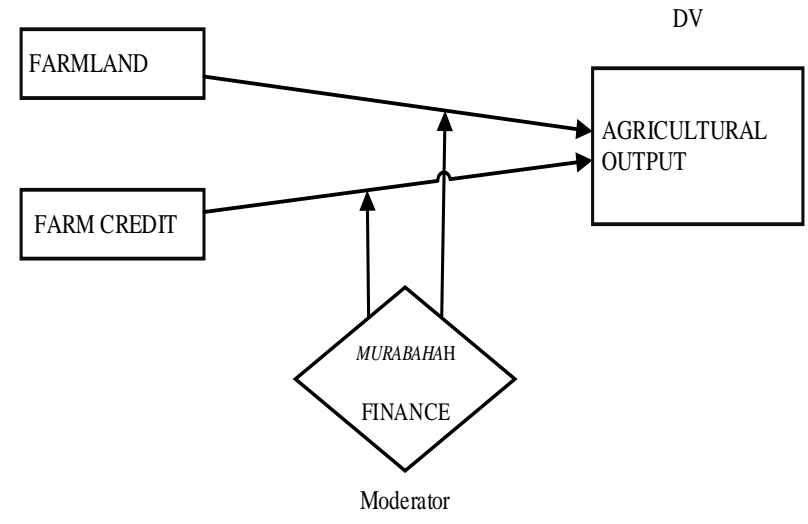

Fig. 1.1: Proposed Frameworks of Farmland, Formal Credit and agricultural Output.

In explaining the relationship between farmland and farm credit on agricultural output, the present paper proposes the extent to which Murabahah finance influences farmland and farm credit on agricultural output. This indicated that Murabahah finance influences the relationship between farm input and output as a well selected farm input is subjected to the increase in farm output. This is relevant to the Cobb- Douglas theory of production function as per previous empirical studies reported (27). Based on the prior findings farmland and farm credit have influenced on agricultural output as farmers with Murabahah finance had higher agricultural output than farmers without Murabahah finance. Furthermore, building on the general hedonistic perspective, farmers seek to minimized cost of farm input and maximized agricultural output in their productivity (14). Specifically, Cobb Douglas theory of production, "distinguishes agricultural production input and output with other productions in terms of agricultural production function regards to input and output. According to theory of production an increase of farm input is proportional increase in agricultural output.

Secondly, result regarding the moderating effect of Murabahah finance on the relationship between farm land and agricultural output is also in line with theory of production (Chambers, 1988). This research suggests that Murabahah finance acted as a buffer between farm land and agricultural, such as farmers with Murabahah finance ware engage in higher agricultural output than farmer without Murabahah finance. In other words, this finding suggests that farmers of Murabahah finance are likely to produce higher agricultural output regardless of cost of production. More importantly, this result showed that those farmers with Murabahah finance are in position of higher agricultural output.

\section{Results}

The finding of the current research has practical implications to the agricultural sector of Kano state. Firstly, the results suggest that perceptions of Kano state farmers on shariah financial product are important toward promoting agricultural output in Kano state. Also, Kano state farmers can make considerable efforts in utilizing shariah agricultural financial product with aims of increasing agricultural output (Jinjiri, 2014).

Secondly, the findings suggest that farm inputs were related to agricultural output. In particular, the farm credit, farm land and infrastructure were found to be positively related to agricultural output in the entire sample. Thus, full pledge and window operation financial institutions could increase the likelihood of farmers toward engaging in Shariah farm facilities by providing simple condition that will lead to positive farmer's participation $(34,45)$. For example, management of the shariah financial products might establish farmer's awareness through mass media as well as increase discussion through symposium and workshop.

Finally, as stated at the outset of this report, agricultural input and output is a prevalent and costly phenomenon for agricultural production $(3,13)$. Therefore, the results of the current study suggest that besides conventional agricultural input, Shariah product for agricultural input strategy should be given serious consideration in agricultural sector of Kano state. In particular, the moderating role of Murabahah finance suggests that effective Murabahah financing can maximize the tendencies of farmers to produce more agricultural output. Thus, Kano state ministry of agriculture could consider Murabahah finance as a selection criterion when making decisions.

\section{Conclusion and Recommendations}

The paper discusses the relationship between farmland and farm credit on agricultural output as depicted in figure 1. This model, if validated on empirical bases is expected to contribute to the agricultural financing and Islamic finance and Banking as well as related literature. Taken together, the present study has provided additional evidence to the growing body of knowledge concerning the moderating role of Murabahah finance on the relationship between farm credit, farm land, and agricultural output. Results from this study supported the key theoretical propositions. In particular, the current study has successfully supported the hypothesis. While there have been many studies examining the underlying causes of declined of agricultural output, however, the present study addressed the theoretical gap by incorporating Murabahah finances as a proposed moderating variable.

This study also lends theoretical support for the moderating role of Murabahah finance on the relationship between farm credit, farm land and agricultural output. The theoretical framework of this study is also expected to added to the domain of theory of production by examining the influence of agricultural input and output through examined the effect of farm credit, farm land and agricultural output. In addition to the theoretical contributions, the results from this study provide some important practical implications to the Kano state government through ministry of agriculture, full pledge Islamic bank (Ja'is bank) and window Islamic banking operators (Stanbic ITBC, Kyestone bank) and Islamic micro finance banks, farmers cooperative, subsistence and commercial farmers, agro- business and agro-allied industries, stake holders and managers, both public, privates and nongovernmental organi- 
zations (NGOs). More so, limitations of the current study, several future research directions were all drawn.

\section{References}

[1] TIBI K, Edebiri F. ACCESS TO MICROCREDIT-A SURE WAY OF BREAKING THE VICIOUS CIRCLE OF POVERTY AMONG FARMERS IN ETHIOPE EAST LOCAL GOVERNMENT AREA, DELTA STATE, NIGERIA. 2015.

[2] Ogunbado AF, Ahmed U. Bay'Salam as an Islamic Financial Alternative for Agricultural Sustainability in Nigeria. Journal of Islamic Economics, Banking and Finance. 2015;11(4):63-75.

[3] Ammani AA. Impact of market-determined exchange rates on rice production and import in Nigeria. International Journal of Food and Agricultural Economics (IJFAEC). 2013;1.

[4] Chisasa J. A diagnosis of rural agricultural credit markets in South Africa: empirical evidence from North West and Mpumalanga province. 2014.

[5] Anthony E. Agricultural credit and economic growth in Nigeria: An empirical analysis. Business and Economics Journal. 2010;14:1-7.

[6] THOMSON K. The State of Food and Agriculture 2008: Biofuels: Prospects, Risks and Opportunities. The Journal of Agricultural Science. 2009;147(4):503

[7] Dandago K. Beyond Slogans: How States Hold the Ace for Nigeria's Industrialisation Kano. Benchmark Publishers Ltd; 2005.

[8] Mohammed S, Ibrahim US, Abubakar N. Effect of hike in food prices on households food expenditure in kano state, Nigeria: a case of 2008 global food crisis. 2014

[9] servant T. A Kano State Civil Service. News magazine of May. 2012.

[10] Baron RM, Kenny DA. The moderator-mediator variable distinction in social psychological research: Conceptual, strategic, and statistical considerations. Journal of personality and social psychology. 1986;51(6):1173.

[11] AYEGBA O, IKANI DI. An impact assessment of agricultural credit on rural farmers in Nigeria. 2013.

[12] Akoum IF. Globalization, growth, and poverty: the missing link International Journal of Social Economics. 2008;35(4):226-38.

[13] Ammani AA. An investigation into the relationship between agricultural production and formal credit supply in Nigeria. International Journal of Agriculture and Forestry. 2012;2(1):46-52.

[14] Chambers RG. Applied production analysis: a dual approach: Cambridge University Press; 1988.

[15] Allahyari MS, Poshtiban A, Koundinya V. Effective Factors on Agricultural Land Use Change in Guilan Province, Iran. Mediterranean Journal of Social Sciences. 2013;4(11):744.

[16] Maletta HE. Land and farm production: Availability, use, and productivity of agricultural land in the world. 2014.

[17] Kan I, Haim D, Rapaport-Rom M, Shechter M. Environmental amenities and optimal agricultural land use: The case of Israel. Ecological Economics. 2009;68(6):1893-8.

[18] Jayne TS, Chamberlin J, Headey DD. Land pressures, the evolution of farming systems, and development strategies in Africa: A synthesis. Food Policy. 2014;48:1-17.

[19] Matthew AO, Uchechukwu AA. Rural Farmers Sources and Use of Credit in Nsukka Local Government Area of Enugu State, Nigeria. Asian Journal of Agricultural Research. 2014;8(4):195-203.

[20] Okuthe K, Ngesa U, Ochola W. Influence of Institutional Factors on Adoption of Improved Sorghum Varieties and Technologies by Small-Scale Farmers in Western Kenya. International Journal of Humanities and Social Science. 2013;3(16):196-207.

[21] Simtowe F, Zeller M, Diagne A. The impact of credit constraints on the adoption of hybrid maize in Malawi. Review of Agricultural and environmental studies. 2009;90(1):5-22.

[22] Garrett RD, Lambin EF, Naylor RL. Land institutions and supply chain configurations as determinants of soybean planted area and yields in Brazil. Land Use Policy. 2013;31:385-96.

[23] Bastian CT, McLeod DM, Germino MJ, Reiners WA, Blasko BJ. Environmental amenities and agricultural land values: a hedonic model using geographic information systems data. Ecological economics. 2002;40(3):337-49.

[24] Onyenucheya F, Ukoha O. Loan repayment and credit worthiness of farmers under the Nigerian Agricultural Cooperative and Rural Development Bank (NACRDB). Agricultural Journal. 2007;2(2):265-70.

[25] Nwosu F, Oguoma N, Ben-Chendo N, Henri-Ukoha A. The agricultural credit guarantee scheme: its roles, problems and prospects in Nigeria's quest for agricultural development. Researcher. 2010;2:87-90.

[26] Eyo EO. Macroeconomic environment and agricultural sector growth in Nigeria. World Journal of Agricultural Sciences. 2008;4(6):781-6.

[27] Chisasa J. An Econometric Analysis Of Bank Lending And Agricultural Output In South Africa: A Survey Approach. Journal of Applied Business Research. 2015;31(1):163.

[28] Awe A. Mobilization of domestic financial resources for agricultural productivity in Nigeria. Australian Journal of Business and Management Research. 2013;2(12):1.

[29] Oyeyinka R, Bolarinwa K. Using Nigeria Agricultural Cooperative and Rural Development Bank Small Holder Direct Loan Scheme to increase agricultural production in rural Oyo State, Nigeria. International journal of Agricultural Economics and rural Development. 2009;2(1):2009.

[30] Klinefelter DA, Penson B. Growing complexity of agricultural lending decisions. Choices. 2005;20(1):7-12.

[31] Brambilla I, Porto GG. Farm productivity and market structure: Evidence from cotton reforms in Zambia. 2006.

[32] Bello G. An analysis of the viability of Islamic Banking in Kano state, Nigeria. Usman Dan fodio University Sokoto-Nigeria (Doctoral dissertation $@$ Garba Bello). 2006.

[33] Ayub M. Islamic Finance: Laying Down an Overarching Schema for Value based Sharī 'ah Advisory and Governance Framework. Journal of Islamic Business and Management. 2013;3(2):97-128.

[34] Dandago KI, Muhammad AD, Oseni UA. Essentials of Islamic banking and finance in Nigeria. 2013

[35] Ahmed Hilmy H. Introducing Salam as an alternative financing tool for paddy field cultivation in Sri Lanka: special reference to Eastern province. 2013.

[36] Mastoor SA, editor Islamic Banking System in Afghanistan. Proceedings of International Academic Conferences; 2014: International Institute of Social and Economic Sciences.

[37] Mohammed H, Hussien AIM. The Finance Of Wheat In Gezira Scheme, Sudan. International Working Paper Series Paper, 2012.

[38] Siddiqi MN. Islamic banking and finance in theory and practice: A survey of state of the art. Islamic economic studies. 2006;13(2):148.

[39] Khaleequzzaman M, Shirazib NS. Islamic Microfinance-an Inclusive Approach with Special Reference to Poverty Eradication in Pakistan. International Journal of Economics, Management and Accounting. 2012;20(1).

[40] Obaidullah M. Introduction to Islamic microfinance. 2008.

[41] Obaidullah M, Mohamed-Saleem A. Innovations in Islamic microfinance: lessons from Muslim Aid's Sri Lankan experiment. 2008.

[42] Aburaida KMM. Rural Finance As A Mechanism For Poverty Alleviation In Sudan, With An Emphasis On „Salam "Mode. European Scientific Journal, ESJ. 2014;7(26).

[43] Hair JF, Black WC, Babin BJ. RE Anderson Multivariate data analysis: A global perspective. New Jersey, Pearson Prentice Hall,). 2010.

[44] Ringle CM, Wende S, Becker J-M. SmartPLS 3. Hamburg: SmartPLS. Academy of Management Review. 2014;9:419-45.

[45] Jinjiri Ringim K. Perception of Nigerian Muslim account holders in conventional banks toward Islamic banking products. International Journal of Islamic and Middle Eastern Finance and Management. 2014;7(3):288-305 